\title{
The influence of the season and milking time on the properties and the fatty acid composition of the milk in different dairy cattle farms
}

\author{
Tulay Ozcan ${ }^{1}$, Erkan Yaslioglu², Ilker Kilic², Ercan Simsek ${ }^{2}$ \\ ${ }^{1}$ Uludag University, Department of Food Engineering, 16059 Gorukle, Bursa-Turkey \\ ${ }^{2}$ Uludag University, Department of Biosystems Engineering, 16059 Gorukle, Bursa-Turkey \\ Prispjelo - Received: 26.06.2014. \\ Prihvaćeno - Accepted: 16.01.2015.
}

\begin{abstract}
The fatty acid content and physicochemical composition of the milk obtained from 3 cattle farms at summer and winter season for different milking time were studied. Physicochemical properties varied due to different feeding strategies used in the observed farms. The lowest values of total fat and protein were observed in winter time with the highest fat content of morning milking. The groups of fatty acids (FAs), namely saturated (SAFA), monounsaturated (MUFA) and polyunsaturated (PUFA) were examined together with the individual acids with short and long chains. The major fatty acids of milk samples were myristic, palmitic, stearic and oleic acids. In the summer season the content of unsaturated fatty acid was quantitatively higher than the saturated fatty acid. It can be concluded that the fatty acid composition and quality of milk was significantly depended on breeding, feeding strategies, milking and cattle management practices.
\end{abstract}

Key words: milk, fatty acids, season, milking time

\section{Introduction}

Milk, which has an important role in people's life, is defined as the physiological secretion from the mammary gland of mammals. It contains all therapeutic components such as proteins, fats, essential peptides, amino acids, fatty acids, carbohydrates with vitamins and minerals which are necessary for a balanced diet complete and sufficient ratio (Fox and McSweeney, 1998; Nickerson 1999; Kittivachra et al., 2006).

The composition of milk and its standardization are essential processes to guarantee the quality of milk ingredients and have greatest importance for the dairy industries (Swensson and LindmarkMansson, 2007; Cetin and Ozcan, 2009).

Factors influencing the composition of milk are internal factors like breed of cow, and external factors such as., feeding systems, seasonal changes, conditions in dairy plants, milking frequency and milking systems. The milk composition is affected by environmental conditions such as air temperature, relative humidity, solar radiation, and wind speed. When cows are exposed to hot ambient temperatures it will increase their respiration rate and body temperature or adjust their behavior to maintain their thermal balance (Bennett et al., 1985; Kadzere et al., 2002; Spiers et al., 2004).

Milk fat is one of the principal milk solids. Its' content greatly changes throughout the lactation period and also within a single day. It is a rich source of the saturated fatty acids. Milk fat consists of triacylglycerol, phospholipids, non-esterified fatty acids, and glycerol (Toušová et al., 2013). Researchers have demonstrated that milk fat contains components having positive impact on health and proved to be effective against cancer or coronary heart disease like atherosclerosis. Bovine milk contains a 
large number of fatty acids (FA), including polyunsaturated fatty acids (PUFA) in the n-3 (omega-3) FA group and the conjugated linoleic acid (CLA) isomer cis-9 trans-11 Cl8:2, which have potential benefit to human health (Jensen, 2002). The principal n-3 FA in milk is $\alpha$-linolenic acid (C18:3), along with smaller amounts of eicosapentaenoic acid (C20:5) and docosahexaenoic acid (C22:6). The n-3 FA have been linked to improved neurological function (Contreras and Rapoport, 2002), protection against atherosclerosis (Lee et al., 1994; Bucher et al., 2002; Hu and Willett, 2002), and preventing some forms of cancer (Ip et al., 1991; Rose and Connolly, 1999; Sadatian- Elahi et al., 2004).

The FA profile of bovine milk depends both on the consumed FA and on biohydrogenation processes occurring in the rumen. Thus, many factors also affect the FA composition of bovine milk, including stage of lactation (Gonzáles-Martín et al., 2009), breed and diet composition (White et al., 2001; Cieslak et al., 2010; Kalač and Samková, 2010), season (Lock and Garnsworthy, 2003), geographical location (Thorsdottir et al., 2004a), access to fresh grazing (Hebeisen et al., 1993; Kelly et al., 1998; Knowles et al., 2006), grazing sward type (Hauswirth et al., 2004), silage type (Dewhurst et al., 2003), cereal feeding and oil supplementation of feed (Grummer, 1991; Offer et al., 2001; Wijesundera et al., 2003; Palmquist et al., 2006).

Milk fat can contain up to 400 different FAs (Collomb et al., 2000; 2002a,b), however, recent studies of milk fat are dealing with proportion of saturated (SAFAs), monounsaturated (MUFAs) and polyunsaturated (PUFAs) acids (Zegarska et al., 2001; Sterna and Jemeljanov, 2003; Pešek et al., 2005). There is limited information in the literature on the FA profile of the raw milk produced in Marmara and West Anatolia areas of Turkey (Cetin and Ozcan, 2009). Hence more detailed knowledge of factors affecting FA composition is necessary. The objective of this study was to assess the quality of raw milk from the local dairy industry by analyzing its nutrient content, to investigate the effects of season and milking time on milk FA composition in conventional farms in the Bursa region of Turkey.

\section{Materials and methods}

\section{Milking and milk samples}

Raw milk samples were collected from 3 farms, which were consisted of farm I-FI (40 cows/farm, free stall dairy barn), farm II-FII (63 cows/farm, free stall dairy barn), and 1 major dairy processing companies FIII ( $>72$ cows/farm, open front dairy barn), at Bursa in Northwest Turkey. The farms are applying continuous feeding with standards total mixed rations. The average age of the cows was about 40 to 60 months. Parity of cows was $1-3$, and milk yield $17-35 \mathrm{~kg} /$ day. The cows were milked at 05.30 a.m. and 17.30 p.m. in a cowshed tied to stalls. The milk samples in sterile screw-topped bottles (1 L) from each farm were individually collected at the delivery site of the farms in the morning and evening from companies as a mix from collection tanks, after stirring the bulk tank for minimum of $2 \mathrm{~min}$. Samples stored in ice-box up to the lab and frozen at $-20^{\circ} \mathrm{C}$ till the analyses. Milk data were compiled at different seasonal periods (Summer; March to July and Winter; October to February) between the years of 2008-2009, and all analysis and enumerations were done in duplicate.

\section{Milk composition analysis}

In the laboratory, milk samples were warmed to $40{ }^{\circ} \mathrm{C}$ in a water bath and thoroughly mixed to disperse milk fat homogeneously, without damaging the globule membrane. Sample temperature was $25^{\circ} \mathrm{C}$ for each analysis. The $\mathrm{pH}$ of the milk samples were monitored by a pH meter (Hanna HI 2211 02; Woonsocket, RI, USA). The fat (Gerber method), dry matter and solid-not-fat contents of milk samples were determined according to Kurdal et al. (2011). The total protein (TP) contents were determined using a Kjeldahl method and calculated as: $\mathrm{TP}=$ Total Nitrogen $(\mathrm{TN}) \times 6.38($ AOAC 2000).

\section{Determination of fatty acids}

The FA composition of milk collected from daily milking was analyzed twice using GC-MS to determine the content of approximately fatty acid methyl esters (FAMEs). The lipids from milk samples were extracted using a chloroform-methanol mixture $(2: 1, \mathrm{v} / \mathrm{v})$ according to Bligh and Dyer (1959) and Cruz-Hernandez et al. (2007). Cold 
esterification was carried out to obtain fatty acids methyl esters (FAMEs) according to IUPAC (International Union of Applied and Pure Chemistry) method (Commission Regulation (EC) No 796/2002 of 6 May 2002). The FAMEs were analyzed using a gas chromatograph (Agilent 6890N Series, HewlettPackard Co., Avondale, PA, USA) equipped with flame ionization detector and a capillary column (Agilent DB23 column; $60 \mathrm{~m}, 0.25 \mathrm{~mm}$ i.d, J\&W Scientific Co., Folsom, CA, USA) on a split mode. The oven temperature was programmed as follows: the initial temperature $\left(130^{\circ} \mathrm{C}\right)$ was raised to $170{ }^{\circ} \mathrm{C}$ at a rate of $6.5^{\circ} \mathrm{C} / \mathrm{min}$ and was held at this temperature for $1 \mathrm{~min}$, then was increased at $2.15{ }^{\circ} \mathrm{C} / \mathrm{min}$ to $215^{\circ} \mathrm{C}$ and was held at this temperature for 12 min, and then was increased to $230{ }^{\circ} \mathrm{C}$ and was held at this temperature for $3 \mathrm{~min}$. Nitrogen was the carrier gas and sample injection volume was $1 \mu \mathrm{L}$. The identification of the peaks was achieved by retention times and by comparing them with authentic standards analyzed under the same conditions. Peak areas of triplicate injections were measured with an HP computing integrator. Results were expressed as percentage of total fatty acids.

\section{Statistical analysis}

All samples were analyzed in duplicate and the experiment was repeated three times. Data were analyzed by analysis of variance using MINITAB V.14.1 (MINITAB Inc., USA, 2003) and the differences observed among the samples were determined by the LSD test at $\mathrm{P}<0.01$ and $\mathrm{P}<0.05$.

\section{Results and discussion}

\section{Milk composition}

The amount of milk components varies with breed, parity, milking frequency, physiological and nutritional status of animals (Palmquist et al., 2006). Compositions of milk in various dairy farms in summer and winter time were presented in Table 1. The lowest values of total fat and protein were observed in winter time $(3.64 \pm 0.03$ and $3.39 \pm 0.06$ g $100 \mathrm{~g}^{-1}$, respectively) and the highest fat content with morning milking time $\left(3.87 \pm 0.04 \mathrm{~g} 100 \mathrm{~g}^{-1}\right.$, respectively) $(\mathrm{P}<0.01)$. As expected, the total dry matter had increased by the increase in fat content. Fat values were higher in FIII in summer time.

Table 1. Composition of milk in various dairy farms

\begin{tabular}{|c|c|c|c|c|c|c|c|c|c|c|}
\hline \multirow{2}{*}{$\begin{array}{l}\text { Nutrient } \\
\left(\mathrm{g} 100 \mathrm{~g}^{-1}\right)\end{array}$} & \multirow{2}{*}{$\begin{array}{l}\text { Milking } \\
\text { time }\end{array}$} & \multicolumn{3}{|c|}{ Summer } & \multicolumn{3}{|c|}{ Winter } & \multirow{2}{*}{$\begin{array}{l}\text { Mean } \\
\text { value }\end{array}$} & \multirow{2}{*}{$\begin{array}{c}\begin{array}{c}\text { Significant } \\
\text { level } \\
(\mathrm{P} \text { value })^{\mathrm{a}}\end{array} \\
\text { Milking time }\end{array}$} & \multirow{2}{*}{$\begin{array}{c}\begin{array}{c}\text { Significant } \\
\text { level } \\
\text { (P value })^{\mathrm{a}}\end{array} \\
\text { Season } \\
\end{array}$} \\
\hline & & FI & FII & FIII & FI & FII & FIII & & & \\
\hline \multirow{2}{*}{ Fat } & Morning & 3.90 & 3.65 & 4.08 & 3.98 & 3.90 & 3.68 & 3.87 & \multirow{2}{*}{$* *$} & \\
\hline & Evening & 3.47 & 3.80 & 3.88 & 4.00 & 2.57 & 3.72 & 3.57 & & \\
\hline Mean value & & & 3.71 & & & 3.64 & & & & $* *$ \\
\hline \multirow{2}{*}{ Total solid } & Morning & 11.61 & 11.44 & 12.59 & 12.16 & 11.13 & 12.30 & 11.87 & \multirow[t]{2}{*}{ ns } & \\
\hline & Evening & 11.25 & 11.71 & 12.34 & 12.21 & 11.42 & 12.15 & 11.85 & & \\
\hline Mean value & & & 11.82 & & & 11.90 & & & & ns \\
\hline \multirow{2}{*}{$\begin{array}{l}\text { Milk solid- } \\
\text { not-fat }\end{array}$} & Morning & 7.71 & 7.79 & 8.51 & 8.18 & 7.23 & 8.42 & 7.97 & \multirow[t]{2}{*}{$* *$} & \\
\hline & Evening & 7.78 & 7.91 & 8.46 & 8.21 & 8.85 & 8.43 & 8.27 & & \\
\hline Mean value & & & 8.03 & & & 8.22 & & & & $* *$ \\
\hline \multirow{2}{*}{ Protein } & Morning & 3.56 & 3.54 & 3.26 & 3.76 & 3.51 & 3.16 & 3.47 & \multirow[b]{2}{*}{ ns } & \\
\hline & Evening & 3.36 & 4.19 & 3.18 & 3.42 & 3.42 & 3.09 & 3.44 & & \\
\hline Mean value & & & 3.73 & & & 3.39 & & & & $* *$ \\
\hline \multirow{2}{*}{$\mathrm{pH}$} & Morning & 6.76 & 6.66 & 6.64 & 6.63 & 6.54 & 6.68 & 6.65 & \multirow[b]{2}{*}{ ns } & \\
\hline & Evening & 6.75 & 6.47 & 6.66 & 6.60 & 6.48 & 6.67 & 6.60 & & \\
\hline Mean value & & & 6.66 & & & 6.60 & & & & ns \\
\hline
\end{tabular}

aP- values are: ${ }^{*} \mathrm{P}<0.05 ;{ }^{* *} \mathrm{P}<0.01 ;$ ns, non-significant

FI: Farm I (40 cows/farm), FII: Farm II (63 cows/farm), FIII: Farm III ( $>72$ cows/farm) 
Table 2. Fatty acid composition of milk samples (g $100 \mathrm{~g}^{-1}$ of lipids)

\begin{tabular}{|c|c|c|c|c|c|}
\hline \multirow{2}{*}{ Fatty acid ${ }^{a}$} & \multicolumn{2}{|c|}{ Summer } & \multicolumn{2}{|c|}{ Winter } & \multirow[b]{2}{*}{ P-value } \\
\hline & Morning & Evening & Morning & Evening & \\
\hline \multicolumn{6}{|l|}{ SCFA } \\
\hline C4:0 Butyric acid & 3.00 & 3.24 & 3.21 & 3.01 & $* *$ \\
\hline C6:0 Caproic acid & 1.90 & 1.95 & 2.05 & 1.98 & $* *$ \\
\hline \multicolumn{6}{|l|}{ MCFA } \\
\hline C8:0 Caprylic acid & 1.19 & 1.12 & 1.33 & 1.30 & $* *$ \\
\hline C10:0 Capric & 2.82 & 2.57 & 2.95 & 3.05 & $* *$ \\
\hline C12:0 Lauric & - & 0.29 & 0.07 & 0.72 & $* *$ \\
\hline C14:0 Myristic & 11.67 & 10.77 & 11.49 & 11.69 & $* *$ \\
\hline C14:1 Myristoleic & 0.23 & 0.19 & 0.46 & 0.61 & $* *$ \\
\hline C15:0 Pentadecanoic acid & 0.05 & - & 2.97 & 0.46 & \\
\hline C15:1 cis-10- Pentadecanoic acid & 0.26 & 0.27 & 0.23 & 0.29 & $*$ \\
\hline \multicolumn{6}{|l|}{ LCFA } \\
\hline C16:0 Palmitic acid & 40.98 & 38.48 & 36.61 & 35.69 & $* *$ \\
\hline C16:1 Palmitoleic acid & 2.57 & 2.31 & 1.94 & 2.19 & $* *$ \\
\hline C17:0 Heptadecanoic acid & 0.75 & 0.58 & 0.66 & 0.55 & $* *$ \\
\hline C17:1 cis-10- Heptadecanoic acid & 0.37 & 0.37 & 0.27 & 0.33 & $* *$ \\
\hline Cl8:0 Stearic acid & 8.09 & 9.36 & 10.04 & 8.99 & $* *$ \\
\hline c C 18:1 Oleic acid & 21.09 & 24.45 & 23.97 & 25.34 & $* *$ \\
\hline$t$ C 18:1 trans Elaidic acid & 3.60 & 2.18 & 0.25 & 0.46 & \\
\hline C 18:2 Linoleic acid & 3.70 & 3.73 & 3.74 & 4.28 & \\
\hline C18:3 Linolenic acid & 0.33 & 0.33 & 0.32 & 0.32 & ns \\
\hline \multicolumn{6}{|l|}{ VLCFA } \\
\hline C20:0 Arachidic acid & 0.14 & 0.13 & 0.11 & 0.08 & ns \\
\hline C20:1 Eicosenoic acid & 0.10 & 0.10 & 0.08 & 0.06 & $* *$ \\
\hline C20:3 cis-8-11-14-Eicosatrienoic acid & 0.31 & 0.28 & 0.28 & 0.26 & $* *$ \\
\hline C22:0 Erusic acid & 0.06 & - & 0.04 & 0.04 & $* *$ \\
\hline C24:0 Lignoceric acid & 0.08 & - & 0.04 & 0.04 & $* *$ \\
\hline
\end{tabular}

aP-values are: ${ }^{*} \mathrm{P}<0.05 ;{ }^{*} \mathrm{P}<0.01 ;$ ns, non-significant

Abbreviations: Short-chain fatty acids (SCFA, C4:0 to C6:0); Medium-chain fatty acids (MCFA; C8:0 to C15:1); Long-chain fatty acids (LCFA; C16:0 to C18:3); Very long chain fatty acids (VLCFA, longer than 19 carbons)

Depending on milking, seasonal and regional differences milk composition are important for the manufacturer of dairy products. These results (total solid- TS, milk solid-not-fat- MSNF) varied due to different strategies used in the observed farms. Especially the variation in the fat content and nitrogen fraction (casein and total nitrogen) of milk affects the product yield, gelling and renneting time, flavour and texture of a fermented dairy products and cheeses (Mehra et al., 1999).
Protein and fat values were higher in summer time. Protein content may be also influenced by the breed, lactation period, season and the feeding status, while the fat content reflects supplementary feeding, the effects of sub-clinical mastitis, breed, age and lactation period. $\mathrm{pH}$ values were also determined in this investigation (Table 1). The $\mathrm{pH}$ of milk varied from 6.47 up to 6.75 in the summer and 6.48 up to 6.68 in the winter time. The $\mathrm{pH}$ values did not differ between farms, farm conditions, season 
and milking time $(\mathrm{P}>0.01)$. The milk MSNF content was lowest in the morning milking $(7.97 \pm 0.07$

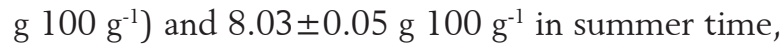
corresponding to areas with lower and higher protein and fat content.

\section{Fatty acid composition}

Many factors are associated with variations in the amount and fatty acid composition of bovine milk lipids. They may be of animal origin, which includes genetics, stage of lactation, mastitis and ruminal fermentation, or they may be feed-related factors, which comprise fibre and energy intake, dietary fats, seasonal and regional effects (Beaulieu and Palmquist, 1995; Delbecchi et al., 2001; De Peters et al., 2001; Jensen, 2002).

The fatty acid composition in milk fat is given in Table 2. The fatty acid content varied throughout milking time and season. The major differences between milk samples were observed in fatty acids but milking time and summer did not lead to any significant variations $(\mathrm{P}>0.01)$ in the average values of linolenic acid (C18:3) and arachidic acid (C20:0) (Table 3).
The content of FAs could be influenced with location and farm size, too. Nevertheless, diet is the most important factor affecting milk composition particularly the FA composition of ruminant milk (Dewhurst et al., 2003). Researchers established, that milk from cows fed fresh green forage, especially those grazing grass, had a significantly higher unsaturated with more polyunsaturated FA and more CLA, than the milk from silage fed cows had with low saturated fatty acid composition (Jahreis et al., 1997; Drackley et al., 2001; White et al., 2001; Bargo et al., 2006; Ellis et al., 2006). Acids $18: 2 n-6$ and $18: 3 n-3$ was the main PUFAs in milk fat as reported by Dewhurst et al. (2006).

Milk samples collected in winter time and evening milk had the highest content of 18:2n-6 $(\mathrm{P}<0.01)$. The content of $\alpha$-linolenic acid (ALA), the precursor of the longer chain omega-3 fatty acids (Simopoulos, 2009), are considerable because the dietary ingestion of ALA due to do prevent cardiovascular disease (Zhao et al., 2007).

The composition of the fat influences the fat properties and the technological processes in dairy plants. Additionally, the long-chain fatty acids

Table 3. Fatty acid profiles of milk samples (g $100 \mathrm{~g}^{-1}$ of lipids), according to the carbon chain length

\begin{tabular}{|c|c|c|c|c|c|}
\hline \multirow[b]{2}{*}{ Fatty acid ${ }^{a}$} & \multicolumn{2}{|c|}{ Summer } & \multicolumn{2}{|c|}{ Winter } & \multirow[b]{2}{*}{ P-value } \\
\hline & Morning & Evening & Morning & Evening & \\
\hline SCFA & 4.90 & 5.19 & 5.26 & 4.99 & $* *$ \\
\hline MCFA & 16.22 & 15.21 & 19.50 & 18.12 & $* *$ \\
\hline LCFA & 81.48 & 81.79 & 77.80 & 78.15 & $* *$ \\
\hline VLCFA & 0.69 & 0.51 & 0.55 & 0.48 & ns \\
\hline
\end{tabular}

aP- values are: ${ }^{*} \mathrm{P}<0.05 ;{ }^{*} \mathrm{P}<0.01 ;$ ns, non-significant

Abbreviations: Short-chain fatty acids (SCFA, C4:0 to C6:0); Medium-chain fatty acids (MCFA; C8:0 to C15:1); Long-chain fatty acids (LCFA; C16:0 to C18:3); Very long chain fatty acids (VLCFA, longer than 19 carbons)

Table 4. Fatty acid profiles of milk samples (g $100 \mathrm{~g}^{-1}$ of lipids), according to the saturation degree of the carbon chain

\begin{tabular}{cccccc}
\hline & \multicolumn{3}{c}{ Summer } & \multicolumn{3}{c}{ Winter } & \multirow{2}{*}{ Patty acidue $^{\mathrm{a}}$} \\
\cline { 2 - 5 } & Morning & Evening & Morning & Evening & $*$ \\
SAFA & 70.73 & 68.49 & 71.57 & 67.60 & $* *$ \\
MUFA & 28.22 & 29.87 & 27.2 & 29.28 & $* *$ \\
PUFA & 4.34 & 4.34 & 4.34 & 4.86 & $* *$ \\
\hline
\end{tabular}

aP- values are: ${ }^{*} \mathrm{P}<0.05 ;{ }^{* *} \mathrm{P}<0.01 ;$ ns, non-significant

Abbreviations: Saturated Fatty Acid (SAFA); Monounsaturated Fatty Acid (MUFA); Polyunsaturated Fatty Acid (PUFA) 
(LCFA) have a desirable effect on human health (Collomb and Bühler, 2000; Libby, 2002). The quantities of fatty acids in milk according to carbon chain length presented in Table 3. The shortchain fatty acid (SCFA) levels were low because of less butyric (C4:0) and caproic (6:0) acid contents. Compared to the milk samples the content of the medium-chain fatty acids (MCFA) was significantly higher $(\mathrm{P}<0.01)$ in morning milking time during winter season, and the content of LCFA was higher in summer time, considering both milking time (Table 3) constituted the highest lipid fraction in all samples. The contents of very long-chain fatty acids (VCFA) in milk samples ranged from 0.48 to $0.69 \mathrm{~g}$ $100 \mathrm{~g}^{-1}$ of lipids and were no significant differences observed $(\mathrm{P}<0.01)$.

Saturated fatty acids are made up of C4-C18 long fatty acids, with palmitic, myristic and stearic acids. According to degree of saturation of carbon chain, shown in Table 4, the content of SAFA in the

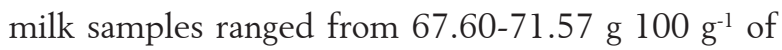
lipids and was the highest in morning milk samples with summer time $(\mathrm{P}<0.01)$. The highest levels for monounsaturated fatty acids (MUFA) and polyunsaturated fatty acids (PUFA) were detected in milk samples with evening milking time in summer and evening milking time in winter $\left(29.28 \mathrm{~g} 100 \mathrm{~g}^{-1}\right.$ and

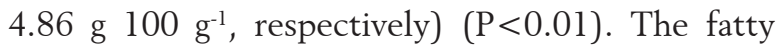
acid $c \mathrm{Cl} 8: \ln 9$ predominated as the MUFA with the highest content in the milk samples and in milk sample with winter time was higher than in the summer time. Polyunsaturated fatty acids are synthesized as an intermediate product in ruminal biohydrogenation (Griinari et al., 1996; Murphy et al., 2000; Laugalis et al., 2004). This variation could be due to a difference in fermentation by the rumen microorganisms due to different fodders.

The higher level of long-chain, was due to the increase of unsaturated, monounsaturated, or polysaturated acids in milk fat. These fatty acids indicates high body fat mobilization due to energy deficit. The level of these fatty acids may be attributed to metabolic process of the cow, including fermentation in the rumen. This contributes to a decrease in saturated fatty acids. Energy deficit has a significant effect on the decrease of C4, C6, C8, C10, C12, and $\mathrm{Cl}$, and on the increase of C18, C18:1, C18:2 (Lindmark-Mansson et al., 2003).
Seasonal effect was the important decrease of the SFAs and a slight increase of poly-unsaturated fatty acids (LCFA and VLCFA) at summer (Table 3 ). The content of unsaturated fatty acids decrease in winter and in spring depends on animal feed which is quite poor and composed mainly of cellulose at that time (Lock and Garnsworthy, 2002, 2003; Lucas et al., 2006). Cetin and Ozcan (2009) observed fatty acid composition of raw milk produced in Marmara and West Anatolia areas of Turkey shows that the most abundant FAs were palmitic, oleic, myristic and stearic acid. The data revealed that saturated fatty acids were predominant (average of

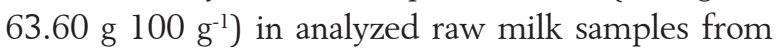
Marmara and West Anatolia areas of Turkey.

Increasing the overall total PUFAs of the diet is considered beneficial to human health with respect to reducing cardiovascular disease and cancer research have mainly focused on these fatty acids. However, high level of unsaturation increases lipid oxidation which could affect the quality of the dairy products due to the development of the off-flavour (Hu and Willett, 2002).

Chilliard et al. (2001) and Voigt and Hagemeister (2001) reported that altering the composition of milk to provide a better source of PUFA and reduce the SAFAs content. So, it is essential to determine the seasonal, herd-level management, and nutritional factors that affect milk FA composition, which will allow the formulation of recommendations for producers aiming to enhance the content of beneficial FA in milk.

Salamon et al. (2006) reported that the milk fat in summer consists of more linoleic acid, linolenic acid, oleic acid and CLA than in winter. Since the animals were kept under the same feeding conditions and mainly consuming grass in summer and hay and silage in winter, the higher unsaturated fatty acid content of the summer milk might be because of higher CLA content or the influence of the higher ultraviolet radiation.

\section{Conclusion}

This study showed that significant seasonal variations were observed in fat content, with the highest values occurring in summer and the lowest in winter. However, recent research and commercial interests 
want to increase the levels of monounsaturated and polyunsaturated fatty acids (especially of omega-3 fatty acids and conjugated linoleic acid- CLA) in milk using different technological methods. In the summer season the content of unsaturated fatty acid was higher than the saturated fatty acids. The major fatty acids of milk samples were myristic, palmitic, stearic and oleic acids. It was clear that the general composition in fatty acids was mainly under the influence of environmental conditions (the region was the reflection of feeding conditions) more than genetic factors. These results will help to explain dairy manufacturers the importance of quality factors of raw milk that fluctuates depending on the feeding practices and dairy plant management. Further detailed work is essential to understand the regional and seasonal effects on milk fat composition.

\section{Utjecaj sezone i vremena mužnje na svojstva i sastav masnih kiselina u mlijeku na različitim farmama mliječnih krava}

\section{Sažetak}

U radu je istražen sastav masnih kiselina i fizikalno-kemijski sastav mlijeka ljetnog i zimskog perioda, te različitih termina mužnje sa 3 mliječne farme. Fizikalno-kemijska svojstva varirala su s obzirom na korištene različite strategije hranidbe na farmama. Najniže vrijednosti ukupne masti i proteina uočene su u zimskom razdoblju s najvišim sadržajem masti jutarnje mužnje. Skupine masnih kiselina (MK), odnosno zasićene (SAFA), mononezasićene (MUFA) i polinezasićene (PUFA) utvrđene su zajedno s pojedinačnim kiselinama kratkih i dugih lanaca. Glavne masne kiseline bile su miristinska, palmitinska, stearinska i oleinska kiselina. U ljetnim je mjesecima sadržaj nezasićenih masnih kiselina veći od zasićenih masnih kiselina. Može se zaključiti da je sastav masnih kiselina i kvaliteta mlijeka znatno ovisila o uzgoju, hranidbenoj strategiji i mužnji.

Ključne riječi: mlijeko, masne kiseline, sezona, vrijeme mužnje

\section{Acknowledgments}

This study was funded by the Scientific Research Project Unit of Uludag University (Project No. Z-2008/18). The authors would like to express appreciation for the cooperation of all dairy producers involved in collecting this data.

\section{References}

1. AOAC (2000): Official methods of analysis of AOAC International $\left(17^{\text {th }}\right.$ ed.). Gaithersburg, MD, USA (method number 991.20; 33.2.11).

2. Bargo, F., Delahoy, J., Schroeder, G., Baumgard, L., Muller, L. (2006): Supplementing total mixed rations with pasture increase the content of conjugated linoleic acid in milk, Animal Feed Science and Technology 131, 226-240. doi: dx.doi.org/10.1016/j.anifeedsci.2006.04.017

3. Beaulieu, A.D., Palmquist, D.L. (1995): Differential effects of high-fat diets on fatty-acid composition in milk of Jersey and Holstein cows, Journal of Dairy Science 78, 1336-1344. doi: dx.doi.org/10.3168/jds.S0022-0302(95)76755-8

4. Bennett, I.L., Finch, V.A., Holmes, C.R. (1985): Time spent in shade and its relationship with physiological factors of thermoregulation in three breeds of cattle, Applied Animal Behaviour Science 13, 227-236. doi: dx.doi.org/10.1016/0168-1591(85)90046-2

5. Bligh, E.G., Dyer, N.G. (1959): A rapid method of total lipid extraction and purification, Canadian Journal of Biochemistry and Physiology 37, 911-917. doi: dx.doi.org/10.1139/o59-099

6. Bucher, H.C., Hengstler, P., Schindler, C., Meier, G. (2002): N-3 polyunsaturated fatty acids in coronary heart disease: A meta-analysis of randomized controlled trials, The American Journal of Medicine 112, 298-304. doi: dx.doi.org/10.1016/S0002-9343(01)01114-7

7. Cetin, K., Ozcan, T. (2009): Evaluation of fatty acid composition of raw milk produced in Marmara and West Anatolia areas of Turkey, $3^{\text {rd }}$ International EuroFIR Congress, September 8-10, Vienna, Austria, 182-183.

8. Chilliard, Y., Ferlay, A., Doreau, M. (2001): Effect of different types of forages, animal fat or marine oils in cow's diet on milk fat secretion and composition, especially conjugated linoleic acid (CLA) and polyunsaturated fatty acids, Livestock Production Science 70, 31-48. doi: dx.doi.org/10.1016/S0301-6226(01)00196-8

9. Cieslak, A., Kowalczyk, J. Czauderna, M., Potkanski, A., Szumacher-Strabel, M. (2010): Enhancing unsaturated fatty acids in ewe's milk by feeding rapeseed or linseed oil, Czech Journal of Animal Science 55, 496-504.

10. Collomb, M., Bühler, T. (2000): Analyse de la composition en acides gras de la graisse de lait. Mitteilungen aus Lebensmitteluntersuchung und Hygiene 91, 306-332. 
11. Collomb, M., Eyer, H., Sieber, R. (2002a): Chemische struktur und fettsäureverteilung des milchfettes, Agrarforschung 9, 240-245.

12. Collomb, M., Butikofer, U., Sieber, R., Jeangros B., Bosset, J.O. (2002b): Correlation between fatty acids in cow's milk fat produced in the lowlands, mountains and highlands of Switzerland and botanical composition of the fodder, International Dairy Journal 12, 661-666. doi: dx.doi.org/10.1016/S0958-6946(02)00062-6

13. Contreras, M.A., Rapoport, S.I. (2002): Recent studies on interactions between $n-3$ and $n-6$ polyunsaturated fatty acids in brain and other tissues, Current Opinion in Lipidology 13, 267-272. doi: dx.doi.org/10.1097/00041433-200206000-00006

14. Commission Regulation (EC) No 796/2002 of 6 May 2002 amending Regulation (EEC) No 2568/91 on the characteristics of olive oil and olive-pomace oil and on the relevant methods of analysis and the additional notes in the Annex to Council Regulation (EEC) No 2658/87 on the tariff and statistical nomenclature and on the Common Customs Tariff.

15. Cruz-Hernandez, C., Kramer, J.K.G., Kennelly, J.J., Glimm, D.R., Sorensen, B.M., Okine, E.K., Goonewardene, L.A.,Weselake, R.J. (2007): Evaluating the conjugated linoleic acid and trans 18:1 isomers in milk fat of dairy cows fed increasing amounts of sunflower oil and a constant level of fish oil, Journal of Dairy Science 90, 3786-3801. doi: dx.doi.org/10.3168/jds.2006-698

16. De Peters, E.J., German, J.B., Taylor, S.J., Essex, S.T., Perez-Monti, H. (2001): Fatty acid and triglyceride composition of milk fat from lactating Holstein cows in response to supplemental canola oil, Journal of Dairy Science 84, 929-936. doi: dx.doi.org/10.3168/jds.S0022-0302(01)74550-X

17. Delbecchi, L., Ahnadi, C.E., Kenelly, J.J., Lacasse, P. (2001). Milk fatty acid composition and mammary lipid metabolism in Holstein cows fed protected or unprotected canola seeds, Journal of Dairy Science 84, 1375-1381. doi: dx.doi.org/10.3168/jds.S0022-0302(01)70168-3

18. Dewhurst, R.J., Fisher, W.J. Tweed, J.K.S., Wilkins, R.J. (2003): Comparison of grass and legume silages for milk production. 1. Production responses with different levels of concentrate, Journal of Dairy Science 86, 2598-2611. doi: dx.doi.org/10.3168/jds.S0022-0302(03)73855-7

19. Dewhurst, R.J., Shingfield, K.J., Lee, M.R.F., Scollan, N.D. (2006): Increasing the concentrations of beneficial polyunsaturated fatty acids in milk produced by dairy cows in high-forage systems, Animal Feed Science and Technology 131, 168-206. doi: dx.doi.org/10.1016/j.anifeedsci.2006.04.016

20. Drackley J.K., Beaulieu A.D., Elliot J.P. (2001): Responses of milk fat composition to dietary fat or nonstructural carbohydrates in Holstein and Jersey cows, Journal of Dairy Science 84, 1231-1237. doi: dx.doi.org/10.3168/jds.S0022-0302(01)74584-5

21. Ellis, K.A., Innocent, G., Grove-White, D., Cripps, P., McLean, W.G., Howard, C.V., Mihm, M. (2006): Comparing the Fatty Acid Composition of Organic and Conventional Milk, Journal of Dairy Science 89, 1938-1950. doi: dx.doi.org/10.3168/jds.S0022-0302(06)72261-5
22. Fox, P.F., McSweeney, P.L.H. (1998): Dairy Chemistry and Biochemistry. Blackie Academie and Professional, London, 478 pp.

23. González-Martín, I., Hernández-Hierro, J.M., Revilla, I., Vivar-Quintana, A., Morón-Sancho, R., Salvador- Esteban, J. (2009): A comparative study of the analysis of free fatty acids in cheeses (cow's, ewe's and goat's) with different ripening times using nirs: intact samples and fat extracts, Czech Journal of Food Sciences 27, 114-118.

24. Griinari, J.M., Dwyer, D.A. McGuire, M.A., Bauman, D.E. (1996): Partially hydrogenated fatty acids and milk fat depression, Jounal of Dairy Science 79 (Suppl.1), 177 (abstr).

25. Grummer, R.R. (1991): Effect of feed on the composition of milk fat, Journal of Dairy Science 74, 3244-3257. doi: dx.doi.org/10.3168/jds.S0022-0302(91)78510-X

26. Hauswirth, C.B., Scheeder, M.R.L., Beer, J.H. (2004): High n-3 fatty acid content in Alpine cheese - The basis for an Alpine paradox, Circulation 109, 103-107. doi: dx.doi.org/10.1161/01.CIR.0000105989.74749. DD

27. Hebeisen, D.F., Hoeflin F., Reusch, H.P., Junker, E., Lauterburg, B.H. (1993): Increased concentrations of n-3 fatty acids in milk and platelet rich plasma of grass fed cows, International Journal for Vitamin and Nutrition Research 63, 229-233.

28. Hu, F.B., Willett, W.C. (2002): Optimal diets for prevention of coronary heart disease, Journal of the American Medical Informatics Association 288, 2569-2578. doi: dx.doi.org/10.1001/jama.288.20.2569

29. Ip, C., Chin, S.F., Scimeca, J.A., Pariza, M.W. (1991): Mammary cancer prevention by conjugated dienoic derivative of linoleic acid. Cancer Research 51, 61 18-6124.

30. Jensen, R.G. (2002): The composition of bovine milk lipids, Journal of Dairy Science 85, 295-350. doi: dx.doi.org/10.3168/jds.S0022-0302(02)74079-4

31. Kadzere, C.T., Murphy, M.R., Silanikove, N., Maltz, E. (2002): Heat stress in lactating dairy cows: a review, Livestock Production Science 77, 59-91. doi: dx.doi.org/10.1016/S0301-6226(01)00330-X

32. Kalač, P., Samková, E. (2010): The effects of feeding various forages on fatty acid composition of bovine milk fat: A review, Czech Journal of Animal Science 55, 521-537.

33. Kelly, M.L., Kolver, D.E., Bauman, D.E., Van Amburgh, M.E., Muller, D.L. (1998): Effect of intake of pasture on concentrations of conjugated linoleic acid in milk of lactating cows, Journal of Dairy Science 81, 1630-1636. doi: dx.doi.org/10.3168/jds.S0022-0302(98)75730-3

34. Kittivachra, R., Sanguandeekul, R., Sakulbumrungsil, R., Phongphanphanee, P., Srisomboon, J. (2006): Determination of essential nutrients in raw milk, Songklanakarin Journal Science Technology 28, 115-120.

35. Knowles, S.O., Grace, N.D., Knight, T.W., McNabb, W.C., Lee, J. (2006): Reasons and means for manipulating the micronutrient composition of milk from grazing dairy cattle, Animal Feed Science and Technology 131, 154-167. doi: dx.doi.org/10.1016/j.anifeedsci.2006.04.015

36. Kurdal, E., Ozcan, T., Yilmaz, L. (2011): Milk Technology, Uludag University. Hardcopy Lecture Notes. 240 p. 
37. Laugalis, J., Želvytė, R., Ramanauskienè, J., Monkevičienè, I., Sederevičius, A., Makauskas, S., Kantautaitè, J. (2004): The impact of different feeding technologies on the rumen microflora in dairy cows, Veterinarija ir Zootechnika 25, 16-20.

38. Lee, K.N., Kritchevsky, D., Pariza, M.W. (1994): Conjugated linoleic acid and atherosclerosis in rabbits, Atherosclerosis 108, 19-25. doi: dx.doi.org/10.1016/0021-9150(94)90034-5

39. Libby, P. (2002): Inflammation in atherosclerosis, Nature 420, 868-874. doi: dx.doi.org/10.1038/nature01323

40. Lindmark-Mansson, H., Fonden, R., Pettersson, H. E. (2003): Composition of Swedish dairy milk, International Dairy Journal 13, 409-425. doi: dx.doi.org/10.1016/S0958-6946(03)00032-3

41. Lock, A.L., Garnsworthy, P.C. (2002): Independent effects of dietary linoleic and lonolenic fatty acids on the conjugated linoleic acid content of cows' milk, Animal Science 74, 163-176.

42. Lock, A.L., Garnsworthy, P.C. (2003): Seasonal variation in milk conjugated linoleic acid and 49 -desaturase activity in dairy cows, Livestock Production Science 79, 47-59. doi: dx.doi.org/10.1016/S0301-6226(02)00118-5

43. Lucas, A., Agabriel, C., Martin, B., Ferlay, A., Verdier Metz, I., Coulon, J.B., Rock, E. (2006): Relationships between the conditions of cow's milk production and the contents of components of nutritional interest in raw milk farmhouse cheese, Lait 86, 177-202. doi: dx.doi.org/10.1051/lait:2005049

44. Mehra, R., O’Brien, B., Connolly, J.F., Harrington, D. (1999): Seasonal variation in the composition of Irish manufacturing and retail milks. 2: Nitrogen fractions, Irish Journal of Agriculture and Food Research 38, 65-74.

45. Murphy, M., Akerlind M., Holtenius, K. (2000): Rumen fermentation in lactating cows selected for milk fat content fed two forage to concentrate ratios with hay or silage, Journal of Dairy Science 83, 756-764. doi: dx.doi.org/10.3168/jds.S0022-0302(00)74938-1

46. Nickerson, S.C. (1999): Milk production: Factors affecting milk composition. In Milk Quality. Harding, F. (ed) Aspen Publishers, Inc. Gaithersburg, Maryland, Aspan, pp: 3-23.

47. Offer, N.W., Speake, B.K. Dixon, J., Marsden, M. (2001): Effect of fish-oil supplementation on levels of (n-3) poly-unsaturated fatty acids in the lipoprotein fractions of bovine plasma, Animal Science 73, 523-531.

48. Palmquist, D.L., Stelwagen, K., Robinson, P.H. (2006): Modifying milk composition to increase use of dairy products in healthy diets, Animal Feed Science and Technology 131, 149-153. doi: dx.doi.org/10.1016/j.anifeedsci.2006.06.011

49. Pešek, M., Špıčka, J., Samková, E. (2005): Comparison of fatty acid composition in milk fat of Czech pied cattle and Holstein cattle, Czech Journal of Animal Science 50, 122-128.

50. Rose, D., Connolly. J.M. (1999): Omega-3 fatty acids as cancer chemopreventive agents, Pharmacology and Therapeutics 83, 217-244. doi: dx.doi.org/10.1016/S0163-7258(99)00026-1
51. Saadatian-Elahi, M., Norat, T. Goudable, J., Riboli. E. (2004): Biomarkers of dietary fatty acid intake and the risk of breast cancer: A meta-analysis, The International Journal of Cancer 111, 584-591. doi: dx.doi.org/10.1002/ijc.20284

52. Salamon, R., Varga-Visi, É., Sára, P., Csapó-Kiss, Zs., Csapó, J. (2006): The influence of the season on the fatty acid composition and conjugated linolic acid content of the milk, Krmiva 48, 193-200.

53. Simopoulos, A.P. (2009): Human requirement for $n-3$ polyunsaturated fatty acids, Symposium: Role of poultry products in enriching the human diet with N-3 PUFA, 961970.

54. Spiers, D.E., Spain, J.N., Sampson, J.D., Rhoads, R.P. (2004): Use of physiological parameters to predict milk yield and feed intake in heat-stressed dairy cows, Journal of Thermal Biology 29, 759-764. doi: dx.doi.org/10.1016/j.jtherbio.2004.08.051

55. Sterna, V., Jemeljanov, A. (2003): Comparison of fatty acids and cholesterol content in the milk of Latvian cows, Veterinária e Zootecnia 22, 95-98.

56. Swensson, C., Lindmark-Mansson, H. (2007): The prospect of obtaining beneficial mineral and vitamin contents in cow's milk through feed, Journal of Animal and Feed Sciences 16, 21-41.

57. Thorsdottir, I., Hill, J., Ramel, A. (2004): Seasonal variation in cis-9, trans-11 conjugated linoleic acid content in milk fat from Nordic countries, Jounal of Dairy Science 87, 2800-2802. doi: dx.doi.org/10.3168/jds.S0022-0302(04)73407-4

58. Toušová, R., Stádník, L., Ducháček, J. (2013). Effects of season and time of milking on spontaneous and induced lipolysis in bovine milk fat, Czech Journal of Food Sciences 31, 20-26.

59. Voigt, J., Hagemeister. H. (2001): Dietary influence on a desirable fatty acid composition in milk from dairy cattle, Journal of Animal and Feed Sciences 10, 87-103.

60. White, S.L., Bertrand, J.A. Wade, M.R. Washburn, S.P., Green, J.T., Jenkins, T.C. (2001): Comparison of fatty acid content of milk from Jersey and Holstein cows consuming pasture or a total mixed ration, Jounal of Dairy Science 84, 2295-2301. doi: dx.doi.org/10.3168/jds.S0022-0302(01)74676-0

61. Wijesundera, C., Shen, Z., Wales, W.J., Dalley. D.E. (2003): Effects of cereal grain and fibre supplements on the fatty acid composition of milk fat of grazing dairy cows in early lactation, Jounal of Dairy Research 70, 257-265. doi: dx.doi.org/10.1017/S0022029903006241

62. Zegarska, Z., Jaworski, J., Paszczyk B., Charkiewicz J., Borejszo, Z. (2001): Fatty acid composition with emphasis on trans C18:1 isomers of milk fat from lowland and Black and White and Polish Red cows, Polish Journal of Food and Nutrition Sciences 10/51, 41-44.

63. Zhao, G., Etherton, T.D., Martin, K.R., Gillies, P.J., West, S.G., Kris-Etherton, P.M. (2007): Dietary $\alpha$-linolenic acid inhibits proinflammatory cytokine production by peripheral blood mononuclear cells in hypercholesterolemic subjects, American Journal of Clinical Nutrition 85, 385-391. 